\title{
The CruCES Project: A Consideration of Service Learning and Intercultural Sensitivity Among Heritage Learners
}

\author{
Diana M. Ruggiero ${ }^{1}$ \\ University of Memphis
}

\begin{abstract}
Though intercultural competence (ICC), community service learning (CSL), languages for specific purposes (LSP), and heritage learners (HLs) have respectively received increasing attention by language scholars within the previous twenty years, much remains to be done in the way of research concerning the relationship between them. The term HLs is used by academics in the United States in reference to students with previous knowledge of the target language and culture as a result of their cultural heritage and upbringing. This article considers the relevance of CSL to HL intercultural competence through a discussion of a 2015 community service learning project and study titled Creating Communities, Engaged Scholarship (CruCES). The project involved students and faculty from the University of Memphis, local non-profit organizations, and community members from the linguistically and ethnically diverse neighborhood of West Binghampton in Memphis, Tennessee (USA). CruCES sought to build capacity and foster community through the development of sustainable micro-economy projects centered on the arts. During the project, students also participated in a study on ISD. This paper considers the implications of the study's findings for HLS specifically. In total, eight of the fifteen participating students self-identified as HLs. The CrUCES project outcomes and study data for participating HLs are most telling with regards to their unique subjective positioning and language learning. Specifically, the study found that participating HLs demonstrated a higher degree of cultural sensitivity at the outset of the project and experienced an increase in self confidence and self-esteem related to the purposeful application of their language skills. A transformational experience for many of the HLs, the CruCES study findings hold significant implications for the development and integration of CSL in LSP courses and HL education.
\end{abstract}

Key words: Languages for Specific Purposes; Community Service Learning; Intercultural Sensitivity Development; Spanish for specific purposes; Spanish for the professions; Heritage Learners.

\footnotetext{
${ }^{1}$ Department of World Languages and Literatures, University of Memphis, 108 Jones Hall, Memphis, TN, 38152 (USA).

E-mail: dmrggero@memphis.edu
} 


\section{RESUMEN}

Aunque la competencia intercultural (ICC), el aprendizaje con servicio a la comunidad (CSL), las lenguas para fines específicos (LSP), y los hablantes de herencia del español (HLs) han recibido, respectivamente, cada vez más atención por los estudiosos del lenguaje en los últimos veinte años, aún queda un largo trecho en el camino de la investigación relativa a la relación entre ellos. El termino HLs es usado por académicos en los Estados Unidos en referencia a estudiantes que tienen conocimiento previo del idioma y cultura gracias a su herencia y crianza. Este artículo considera la relevancia del aprendizaje con servicio a la comunidad en hablantes de herencia del español con respecto al desarrollo de la competencia intercultural. Esto es posible a través de una discusión y estudio sobre un proyecto de aprendizaje de servicio comunitario (2015) denominado Creación de Comunidad y compromiso social (CrUCES). En el proyecto participan estudiantes y profesores de la Universidad de Memphis, organizaciones locales sin fines de lucro, y miembros de la comunidad del barrio, lingüística y étnicamente diversos, de West Binghampton en Memphis, Tennessee (EE.UU.). CruCES fue ideado para crear capacitación y fomentar la formación de comunidad a través del desarrollo de proyectos de micro-economía sostenibles centrados en las artes. Durante el proyecto, los estudiantes también participaron en un estudio sobre el desarrollo de la competencia intercultural. Este documento considera las implicaciones de los resultados del estudio para los hablantes de herencia del español específicamente. En total, ocho de los quince estudiantes, se identificaron como HLs. Los resultados del estudio con respecto a los HLS en el proyecto Cruces son reveladores en cuanto a su posicionamiento y subjetividad única en el aprendizaje de idiomas en la comunidad. En concreto, este estudio reveló que los HLs participantes demostraron un mayor grado de sensibilidad cultural desde el principio del proyecto y experimentaron un aumento de la confianza en uno mismo y la autoestima relacionada con el uso intencional de sus habilidades lingüísticas. Con una experiencia verdaderamente transformadora para muchos de los HLs, el estudio del proyecto CruCES contiene hallazgos que tienen implicaciones importantes para el desarrollo y la integración de CSL en cursos de LSP y la educación para HL.

\section{Palabras claves: Lenguas para Fines Especificos; Aprendizaje Servicio en la Comunidad; Desarrollo de sensibilidad intercultural; Español para fines específicos; Español para las profesiones; Hablantes de herencia del español.}

\section{Introduction}

During the fall of 2015, 15 students in SPAN 4703, an advanced Spanish for the professions course in Memphis, Tennessee (U.S.A.), participated in a community service-learning (CSL) project known as Creating Communities, Engaged Scholarship (CruCES). The objective of the project was to build capacity and foster community among residents in the ethnically and linguistically diverse neighborhood of West Binghampton through the development of arts-based microeconomy projects. A collaborative endeavour, students worked closely with two local non-profit organizations, Caritas Village and El Centro Cultural Latino de Memphis, community project leaders, and other participants from the West Binghampton neighborhood and the greater city of Memphis. In addition, students participated alongside community partners in workshops and discussions on leadership, community, community service learning (CSL), language and culture, and issues related to immigration and U.S. Latino identity.

As a part of the project, students also participated in a study on intercultural sensitivity, the preliminary findings of which were presented at the XV International 
Congress of the European Association of Languages for Specific Purposes (AELFE) at the University of Alcalá in Guadalajara, Spain (see Ruggiero, 2016). An extension thereof, this paper considers the CruCES project and study outcomes and findings as they relate specifically to Heritage Learners (HLs). Among language scholars and educators in the United States, HLs is an academic term adopted since the 1990s in reference to those students who grew up either exposed to or speaking a language other than English in their home (see Beaudrie \& Fairclough, 2012). Though a broad category encompassing a diversity of experiences and relationships with the language and culture in question, it is nonetheless useful for scholars and educators in the U.S. and elsewhere in distinguishing the specific learning needs of this unique group of students. Though few studies exist addressing the connection between CSL and intercultural competence, no studies to date consider the implications of CSL for $\mathrm{HL}$ intercultural sensitivity development (ISD). Given HL interest in LSP and CSL, it is vital that LSP educators consider the potential value of CSL for HL ISD. To this end, this paper asks how and to what extent participation in the CruCES project impacted $\mathrm{HL}$ ISD. Additional questions include how ISD compares to the development of the same in non-HLs, and how CSL project design can be maximized so as to best benefit HLs.

\section{Intercultural Sensitivity and Community Service Learning}

Language educators by now recognize the significance of language education in promoting intercultural competence (ICC) among students (e.g., MLA, 2007). An interdisciplinary field in its own right, ICC is variously defined in terms of attitudes or mindsets, behaviors, and skillsets demonstrative of one's ability to engage effectively and appropriately in intercultural contexts (Spitzberg \& Chagnon, 2009, 7). The diversity of approaches to ICC has led to the proliferation of numerous related terms, including intercultural sensitivity, which can lead to much confusion (Deardorff, 2009; Spitzberg \& Changnon, 2009). Yet it is generally recognized that intercultural sensitivity is fundamental for the acquisition and demonstration of those skills and behaviours indicative of ICC, including language learning. Considering the role of language in intercultural communication and the relationship between language and culture, it is no surprise that much of the literature on ICC from language scholars centers on effective and appropriate language use, or intercultural communicative competence (e.g., Byram, 1997, 2009). Given the nature of the CruCEs project and study, however, this article concerns itself not so much with the linguistic aspects of ICC, but with overall attitudes and behaviors that make possible ICC, or rather with intercultural sensitivity.

Similarly, language educators and scholars by now recognize the value of Languages for Specific Purposes (LSP) and CSL respectively for second language acquisition (SLA), especially as they relate to the American Council on Foreign Language Education's goal areas of foreign language teaching (Abbott \& Lear, 2010; National Standards, 2015). Indeed, The benefits of LSP and CSL for students and communities of the target language are well documented. For example, students learn specialized vocabulary, are motivated to learn and continue with language learning, and acquire professional business contacts and career building opportunities, to name a few of the many 
proven benefits (e.g., Lafford, 2012; Lear, 2012). CSL is likewise shown to benefit students in terms of language acquisition, motivation, career opportunities, knowledge of other cultures, as well as in self-esteem and in attitudes regarding cultural difference and community service (e.g., Barreneche, 2011; Ebacher, 2013; Falce-Robinson \& Strother, 2012; Grassi, Hanley \& Liston, 2004; Hellebrandt \& Varona, 1999; Medina \& Gordon, 2014; Pellettieri, 2011; Pérez-Llantada \& Watson, 2011; Zapata, 2011). These benefits are likewise extended to the community as local organizations receive needed language other skilled help in meeting the needs of local populations in the target language (e.g., Hellebrandt \& Jorge, 2013; Hellebrandt, Arries \& Varona 2003; Lear \& Sanchez, 2013; Lear \& Abbott, 2009). Furthermore, CSL complements and furthers the goals of LSP, as many educators and scholars likewise recognize (e.g., Nelson \& Scott, 2008; Ruggiero 2015).

Yet, with the exception of a few studies, little attention has been given to the relationship between LSP/CSL and ICC, or ISD, within the context of language study. Those studies that have broached the topic, however, have suggested a positive correlation between CSL and ISD. Through observation of student comments in reflection journal assignments over the course of a CSL tutoring project, Kara McBride (2010), for example, found that students most focused on the tutoree's language learning process and project objectives revealed more instances of intercultural sensitivity than those who did not. Furthermore, she found that depth of student reflections was likewise linked to higher instances of intercultural sensitivity. Though McBride admits that there are numerous variables that could account for the disparity between those who did and did not demonstrate intercultural sensitivity, including lack of experience or training in reflective writing, she concludes that student framing of the project was key to the student's perceived experience of the project, and therefore intercultural sensitivity (p. 252). Furthermore, she notes that while students can be taught to write reflectively, doing so might artificially elicit responses indicative of intercultural sensitivity due to student desires to fulfil the assignment requirement as per the expectations of the teacher (p. 257). These findings are also corroborated in a similar study conducted by Silvia Rodriguez-Sabater (2015) that observed student comments in an end of course reflection paper for a Spanish language course. Though students demonstrated varying degrees of intercultural competence as a result of participation in a CSL project, Rodriguez-Sabater likewise found that there was an overall positive correlation between the two that was most evident in the area of what she calls the "mindset," a term taken from Milton Bennett's intercultural competencies framework, discussed below, which refers to attitudes and beliefs (Bennett 2008, pp. 18-21). She likewise suggests that experience with reflective writing may account for low demonstration of ICC among students (McBride, 2010, p. 18).

The studies addressed above confirm that there is indeed a connection between CSL and ISD/ICC. Yet the impact of CSL on HL ISD remains to be considered. This study seeks to bridge this gap and contribute to the existing relevant academic literature on CSL and ISD by addressing HL ISD specifically. 


\section{Metholodology}

\subsection{Course and Project Design}

SPAN 4703 consisted of 15 students during the fall of 2016: 11 females and 4 males ranging in age from 20 to 25 . Of these, 8 were HLs of diverse backgrounds and with varying degrees of Spanish language proficiency ( 6 females and 2 males). For all students, class-time was split between the classroom and the project site, Caritas Village, located in the West Binghampton neighborhood of Memphis, Tennessee: Tuesdays were reserved for the traditional classroom environment while Thursdays were exclusively dedicated to Caritas Village. SPAN 4703 devoted traditional class-time to discussion of assigned readings, supplemental materials, and issues pertinent to the project, CSL, LSP, immigration, and the local and national Latino community. Students worked closely with community leaders on Thursdays at Caritas and also participated in workshops, presentations, and other project activities. In addition to the regular Thursday afternoon meetings at Caritas Village, students were required to commit 28 hours of service learning outside of class. This included time meeting with and supporting community leaders outside of class as well as volunteer work with the free community health clinic operated out of Caritas Village. Many students, for example, volunteered as Spanish language interpreters for the health clinic as well as for other community health fairs and screenings held throughout the city of Memphis.

\subsection{Instruments}

ISD was assessed through surveys and reflection journals. The pre- and post project surveys were anonymous while the journals required students to reflect on their experience through a mixture of digital storytelling and reflective writing. Survey questions ranged in topic from previous CSL experience to the CruCES project and intercultural sensitivity. Using a Likert scale (1 being "strongly disagree" to 5 being "strongly agree"), the survey recorded student perceptions of CSL, awareness of their own respective intercultural sensitivity prior to the project, and the degree to which the CSL experience impacted their intercultural sensitivity after the project. The journals documented student experiences with the CSL project and their developing attitudes through images and writing. Students were asked to photograph any aspect of the CruCEs project they deemed significant to their overall experience with CSL. Journal photographs therefore varied from student to student and consisted of items, objects, and places associated with Caritas and the project as well as fellow classmates, community project leaders, community members, guest speakers, the author, and themselves. Similarly, written journal entries documented student perceptions and attitudes regarding the community, the CruCES project, their experience with CSL, and the issues engaged in class. In addition, students were required to generate critical questions that emerged from their experience with the project. Given the scope and aim of the study, students were given the option to write journal entries in either Spanish or English. Journals were electronically submitted every two weeks for a total of 8 journal entries per student by the end of the project. 


\subsection{Data Analysis}

Journals and survey data were analysed using Milton Bennett's Developmental Model of Intercultural Sensitivity (DMIS) in conjunction with Darla Deardorff's Process Model of Intercultural Sensitivity (PMIS). Bennett's model posits six stages of intercultural sensitivity development, ranging from an ethnocentric mindset to an ethnorelative mindset, through which individuals progress with continued exposure to intercultural contexts (Bennett, 1993, 2004). The three stages in the ethnocentric mindset include denial, defense, and minimization while those of the ethnorelative mindset include acceptance, adaptation, and integration (Ibid.). As suggested by the respective titles, progression along the stages implies the acquisition of skills, behaviors, and attitudes indicative of IC. Similarly, Deardorff's PMIS understands ISD as a continuous process wherein modified behaviors stem from and eventually recursively inform an individual's overall mindset, assumptions, and attitudes (Deardorff, 2006; Deardorff and Edwards, 2013). Rather than define specific stages along a continuum from less to more intercultural sensitivity as in Bennett's DMIS, Deardorff is concerned more with the overall process by which individuals come to develop new mindsets and acquire IC.

Together, Bennett and Deardorff's respective models provide a useful framework for assessing and understanding intercultural sensitivity as it develops over time and with repeated exposure to intercultural contact. Specifically Bennett's continuum from an ethnocentric to ethnorelative worldview provides a useful rubric for determining a student's mindset as illustrated through their reflections (written and visual). The numbers 1 through 6, corresponding to Bennett's six stages of intercultural competence, were assigned to each journal entry based on student visual and written reflections and questions. As per the attitudes and behaviors described within each stage of Bennett's model, student reflections were evaluated for the overall mindset they revealed. Photographs predominantly of objects along with comments such as "I am glad for places like Caritas that help others in need," for example, demonstrate the detached mindset characteristic of Bennett's third stage, minimization. In contrast, photographs predominantly of people and showing developing relationships along with statements such as "I learned a lot from playing with the children who visited Caritas," for example, demonstrate an ethnorelative viewpoint most and would likely be situated within Bennett's fourth stage, acceptance. That said, it is understood that individuals at any given time might demonstrate higher degrees of intercultural sensitivity in some areas while not so in others. Indeed, the journals included many such contradictory statements, often making it difficult to determine whether an individual fell within stage 3 (minimization) or 4 (acceptance), which is the difference between an ethnocentric and ethnorelative mindset. This was remedied, however, through the assignment of half points (i.e., 3.5).

In all cases, student statements were assessed in relation to the whole journal (digital photographs and questions included) as well as in relation to teacher observations, thus more accurately situating student intercultural sensitivity for the time period assessed. Deardorff's model, which focuses predominantly on the process of ISD rather than on the observed outcomes, is useful in illuminating perhaps the most 
significant aspect of intercultural sensitivity, ICC, namely one's attitudes and beliefs (i.e., the mindset). As the starting and end point of Deardorff's model, attitudes are understood to be a precursor and determining factor in the continued development of one's development of intercultural sensitivity and ICC skills and behaviors. As an individual's ICC develops as a result of intercultural contact, so also do their attitudes. A recursive feedback loop, beginning and ending with attitudes, is thus formed between one's attitudes and ICC skills. This is significant for this study in assessing the overall development of intercultural sensitivity among students. As shown below, what seems to be significant is not so much how far an individual progresses along Bennett's model, but the fact that they progress at all. In keeping with Deardorff's model, by the end of the course, students should have attained a transformation in their initial mindset regardless of where they started and how far they progressed during the course of the semester. This transformed mindset, in turn, should better position students to grow even more in their intercultural sensitivity and competence and better orient them as they continue to interact with others beyond the classroom.

\section{HL Journal Findings and DMIS Ratings}

\subsection{Surveys}

Survey results indicate that CSL was indeed beneficial to student ISD. In the preproject survey, students highly rated their intercultural competence and sensitivity. Yet, upon examination of student survey data collected from the exit survey, 13 of the 15 participants agreed or strongly agreed with statements that positively linked their CSL experience with an increase in their intercultural sensitivity (see Table 1: Exit Survey Results). At the same time, at least 2 students consistently disagreed with the same statements. Overall, however, the survey data suggests an increase in intercultural sensitivity in a majority of the project's participants.

\begin{tabular}{lll}
\hline $\begin{array}{l}\text { Survey Questions Correlating CSL and } \\
\text { Intercultural Sensitivity (on a scale of 1 to 5) }\end{array}$ & $\begin{array}{l}\text { Column A } \\
\text { (mean) }\end{array}$ & $\begin{array}{l}\text { Column B } \\
\text { (standard } \\
\text { deviation) }\end{array}$ \\
\hline $\begin{array}{l}\text { Made me more willing to engage in dialogue with } \\
\text { others }\end{array}$ & 4.29 & 1.27 \\
\hline $\begin{array}{l}\text { Helped me better understand people of different } \\
\text { ages, abilities, cultures, or economic backgrounds }\end{array}$ & 4.29 & 1.44 \\
\hline $\begin{array}{l}\text { Encouraged me to consider perspectives other } \\
\text { than my own }\end{array}$ & 4.07 & 1.27 \\
\hline $\begin{array}{l}\text { Helped me to gain more knowledge about the } \\
\text { community with which I worked and the issues } \\
\text { that the community faces }\end{array}$ & 4.14 & 1.23 \\
\hline $\begin{array}{l}\text { Helped me to develop my intercultural } \\
\text { communication skills }\end{array}$ & 4.07 & 1.33 \\
\hline
\end{tabular}

Table 1. Exit Survey Results. 


\subsection{Journal Findings}

Given the number of heritage students involved in the CruCES project, the following addresses the project outcomes and challenges as well as study results as they specifically relate to the HLs and HL needs and concerns. Barring a few minor logistical challenges, the project was a positive experience overall for all participants involved, as indicated by the successful completion of the project products, course survey results, teaching surveys, journals, final projects and portfolios, community leader and community partner comments, and teacher observations. For the HLs in particular, the CSL experience also proved to be personally transformative. HL students, in both their written journal entries and photographs, commented on and demonstrated growth in their interpersonal communication skills, ability to work with others, Spanish language skills, self-esteem and confidence, and attitude overall regarding community service, service learning, and about others (i.e., different people, cultures, etc.) in general. As shown below, these are also corroborated in the increasing DMIS ratings of the HL journals over the course of the semester. The student comments quoted below are presented in their original language and wording.

Common themes emerged among the topics addressed by HL participants in the written journal entries. Specifically, they reflected on community, collaboration, culture, identity, the arts, language, and community service learning. Many $\mathrm{HL}$ and non-HL learners alike, for example commented on Caritas itself and its uniqueness as an open, welcoming, loving, and caring place that invited and facilitated a sense of community. Among the many quotes concerning community, which also tended to focus on Caritas as a site for community building, is the following by one of the HLs:

People of all ages, genders, and races are welcomed there to just enjoy the beauty and daily life of Caritas ... Caritas Village represents a diverse environment that serves as a safe haven for many and a place where anyone can be a part of something special. When my time was up, I didn't want to leave.

Yet others commented on how working together in their groups, with the community partners, and with Caritas helped to strengthen and foster community, such as this comment by another HL student reflecting on a photograph of a school of fish hanging on the wall in Caritas:

... me gustaron mucho porque me recuerdan a cada uno de nosotros.

La razón por cual esta clase es tan divertida es porque nos deja ser más de lo que somos. Esta clase nos ha ayudado a ser mas humanos y aprender a cómo hacer cosas en las cual yo no haría tan seguido.

... I liked them very much because they make me think of each one of us. The reason why this class is so fun is because it allows us to be more than what we are [as individuals]. This class has helped us to be more human and to learn how to do things that I would not do on a regular basis.

Many HLs wrote about culture and identity. In the process, they also reflected on cultural differences, their own cultural identity, social and economic disparities, and the role of language and the arts in overcoming social and cultural differences. For 
example, one HL participant noted how the art project led by his/her community leader, originally from Africa, reflects a distinct set of cultural values informed by unique social conditions.

[Marta] ingeniosamente ve la oportunidad y el potencial de convertir lo en algo nuevo y diferente. Lo que más me gusto es que ella dijo no siempre necesitas dinero para hacer dinero, puedes usar tu creatividad para producir de dinero. Y es que esta forma de pensar solo se puede dar cuando has experimentado escasez y has aprendido a valorar hasta las cosas más sencillas.

[Marta] ingeniously sees the opportunity and potential to convert that [the recycled material] into something new and different. What I liked most is that she said you do not always need money to make money, you can use your creativity to produce money. And it is that this way of thinking only arises when you have experienced need and have learned to appreciate even the most simple things.

Yet another reflected on how his/her own unique cultural identity and bilingual skills might help to bridge language and culture barriers:

When a person knows more than one language, they are able to help people who do not have that skill by translating for them. Interpreters often have better understanding of the cultural norms of the community. They are in a good position to advise [outsiders] on culturally appropriate ways to interact with the community members.

Many HLs took note of how the CruCES arts projects and activities attracted the attention and participation of Caritas patrons. One HL student, for example, noted how a drawing exercise during the leadership exercise, which required participants to visually represent what defines them, allowed them to engage non-English speaking community members:

[Las chicas] no entendían el Inglés muy bien. Yo ayude un poco a interpretar y me dio mucho gusto que quisieran participar y estaban muy enfocadas con lo que estaba pasando [con el grupo]. Siempre es bueno ver a gente así con muchas ganas y valor para hacer cosas diferentes ... nos explicaron sus raíces y cosas que las definan a ellas [usando] un foto que [tenían] que dibujar. Me parece que una de ellas se llamaba María Espinoza. Personas muy buenas y con mucha paciencia con nosotros y los demás en el programa también.

[The girls] do not understand English very well. I helped a little to interpret and it pleased me that they wanted to participate and that they were very focused on what was going on [with the group]. It is always good to see people like that with a desire and courage to try different things.... They explained to us their roots and things that defined them as women [using] a picture that [they had to] draw. It seemed one of them was named Maria Espinosa. Good people and 
who had lots of patience with us and the rest of us in the program [project] too.

Likewise, many of the HLs noted how the group art projects attracted the participation of Caritas patrons, including children, with whom the students developed friendships:

Hice un Nuevo amigo! Este chico es muy agradable. Hable con el para un poco. Yo lo admire porque el no es parte de nuestra clase, pero el todavía quiere ser parte de la experiencia. Estoy tan emocionado que disfrute mas con todos nosotros este semestre.

I made a new friend! This young man is very friendly. I spoke with him for a bit. What I admired about him was that he is not part of our class, but he still wants to be a part of the experience. I am overjoyed I spent such a good time with everyone this semester.

One $\mathrm{HL}$ in particular commented on his/her changing perception on and relationship to art as a process for learning about and engaging with others rather than product:

My jewelry doesn't seem as advanced as the others but I am starting to learn that it is not just about how well you make something-it's the meaning and time behind it. A quote that I often try and go off of is 'Collect moments, not things,' and that is exactly what I am doing right now. These moments I share learning about others [through art making] are precious, and they should be cherished more so than something that is physically tangible. Moments like these are intangible and unforgettable.

Yet another HL demonstrated an awareness of his/her role as a mentor within the community, especially for the children at Caritas:

También conocí a los niños de la comunidad. Eso fue lo que mas me impacto de todo. Con los niños mirándonos hacer una actividad simple y honesta ellos se empiezan a sentir de una forma diferente, empiezan a conocer que hay muchas formas honestas para divertirse y si quieren ser como los niños grandes, pueden.

I also met the kids from the community. That was what most impacted me of everything. With the kids looking at us doing a simple and honest activity, they begin to feel different, they begin to recognize that there are many honest ways to entertain themselves and if they want to be like the big kids, they can.

On service learning, and perhaps most indicative of their overall ISD, all of the HL participants commented on how the CSL experience had impacted them personally by the end of the CruCES project. One HL, for example, noted that not only did his/her language abilities improve, but that his/her confidence in interacting with others also improved as a result: 
Estoy creciendo como líder y como persona, y lo puedo sentir. Estoy creciendo en confianza con el idioma español y la comunidad. Mi gramática española obviamente todavía necesita ayuda, pero que puede suceder durante el semestre. En clase, no quiero tener miedo a decir lo que pienso. Siempre temo que la respuesta que dicen esta mal, pero en esta clase, no hay muchas respuestas incorrectas. A causa de mi nueva confianza, puedo expresar mi opinión. Entro a clase emocionado por un nuevo día en vez de miedo por lo que esta a punto de ser ensenado a la clase.

I am growing as a leader and a person, and I can feel it. I am growing in confidence and in the Spanish language and in the community. My Spanish grammar obviously still needs help, but what [how much] can happen during one semester? In class, I do not want to be afraid to say what I think. I am always afraid that a response [I give] will be bad, but in this class, there are few incorrect responses. As a result of my new confidence, I can express my opinion. I enter class excited for a new day instead of afraid for what is about to be taught to the class.

Similarly, another HL participant noted that his/her growth in confidence in interacting with others in class was also affecting her ability to do so with others outside of class:

Si eh cambiado un poco. Mientras la clase sigue avanzando mas ánimos me entran de convivir con todos y diferentes personas ... Intento interactuar un poco mas con personas alrededor de mi. Eso me ayudado mucho cuando es tiempo de hacer actividades en clase oh Caritas. Me hace sentir un poco cómodo porque lo voy practicando mas día a día y los nervios se me han quitado cuando es tiempo de actuar. Ahora, en cada clase trato de hablar mas con los compañeros de clase y pedir opiniones sobre tareas y trabajos en la clase. También en el publicó ya sea en la farmacia o supermercado trato de ser amigable y saludar con lo mas mínimo a la gente que esta en el mismo lugar que yo.

Yes I have changed a little. As the class advances, I am filled with even more desire to be with everyone and different people.... I try to interact a little bit more with people around me. That helps me a lot when it is time to do activities in class [the traditional classroom] or Caritas. It makes me feel a bit more comfortable because I practice it more day by day [interacting with others] and the nerves have left me when it is time to act. Now, in class I try to speak more with my classmates and ask opinions over assignments and projects related to the class. Also in public, whether in the pharmacy or the supermarket, I try to be friendly and greet people even with if at the most minimum with the people who are in the same place as myself.

The following comment is perhaps most telling with regards to the transformative experience of CSL and how it relates to ISD. As indicated below, he/she is most aware of how participation in the project has shaped his/her overall attitude: 
Community service learning leaves a lasting and even changing effect on your personality. I have come to realize that these services play a major role in reshaping your attitude. My pictures from the beginning are similar to the ones I have now but the way that I view and interpret them are different.

Though the above themes were also addressed by many of the non-HL student participants, HL student reflections differed in that they generally demonstrated a higher degree of cultural sensitivity and were often self-reflexive. Indeed, all of the HLs demonstrated an acute awareness of their own unique cultural identity as well as a sensitivity toward culture and cultural and socio-economic differences from the outset of the project. This was not the case, however, with non-HL participants, some of whom experienced a sort of "culture shock" which then forced them to reflect on their own culture and identity in subsequent journal entries. While this fact did not necessarily translate into greate r overall gains in HL ISD over the course of the project in comparison with the non-HLs, it did mean that HLs started at a higher rating along the DMIS scale, with many beginning either between a 3 and 4 or firmly within the ethnorelative side with a rating of 4 or higher.

The above themes are also evident in the digital photographs taken by the CruCES project HL participants. Many of the photographs taken by the HLs were of the artwork, people, and things that they found most telling of Caritas and its unique sense of community. They also took many photographs not only of the materials and products of the individual group arts projects, but of the student groups, community leaders, and Caritas patrons collaboratively working on the projects and engaging in the workshops. As the photograph subjects chosen by the students were personally meaningful and relevant, they reflected how students felt about or personally related to Caritas, the community, the other students, community project leaders, the groups, and the CruCES project itself. When examined across the duration of the semester, many of the photographs therefore documented the students' developing relationship to Caritas, the community, class, and CruCES project. Thus, they visually documented student growth in intercultural sensitivity. LFE Standard paragraph

\subsection{Journal DMIS Ratings}

The $\mathrm{HL}$ experience of personal transformation during the course of the CruCES project is corroborated in the DMIS ratings of the individual journals. Table 1 shows the individual DMIS scores for each journal as well as the average DMIS scores for HL DMIS scores. As noted previously, the HLs in particular demonstrated a higher degree of cultural sensitivity from the outset of the project, with an average DMIS rating between 3 and 4 in comparison to 2 and 3 for non-HL participants. Overall, the $\mathrm{HL}$ participants demonstrated growth in their intercultural sensitivity throughout the semester, as indicated by the gradual increase in the DMIS rating. On average, HLS experienced a gain of half a point along the DMIS scale (indicated on the Table in the gain column). For six of the students, the gain was significant, with a gain of 1 or more entire points along the DMIS scale. The two remaining HLs experienced no overall 
gain, with one of the students demonstrating no visible increase in DMIS rating and the other showing uneven progression. As noted in the journal entries, however, all students recognized a shift in attitude as a result of participating in the CSL experience despite the fact that their DMIS ratings may not reflect this transformation.

\begin{tabular}{lllllllllll}
\hline Student & Jrnl 1 & Jrnl 2 & Jrnl 3 & Jrnl 4 & Jrnl 5 & Jrnl 6 & Jrnl 7 & Jrnl 8 & Mean & Gain \\
\hline A & 3.5 & 3.5 & 4 & 4 & 4 & 3 & 3.5 & 3.5 & 3.63 & 0.00 \\
\hline B & 4 & 4 & 5 & 5 & 5 & 5 & 5 & 5 & 4.75 & 1.00 \\
\hline C & 3.5 & 3.5 & 4.5 & 4.5 & 4.5 & 4.5 & 5 & 5 & 4.38 & 1.50 \\
\hline D & 4 & 4.5 & 5 & 5 & 5 & 5.5 & 5.5 & 5.5 & 5.00 & 1.50 \\
\hline E & 4.5 & 4.5 & 4.5 & 4.5 & 4.5 & 4.5 & 4.5 & 4.5 & 4.50 & 0.00 \\
\hline F & 3.5 & 3.5 & 4 & 4 & 4 & 4.5 & 4.5 & 4.5 & 4.06 & 1.00 \\
\hline G & 4 & 4.5 & 4.5 & 4.5 & 5 & 5 & 5 & 5 & 4.69 & 1.00 \\
\hline H & 3.5 & 3.5 & 4 & 4 & 4.5 & 4.5 & 5 & 5 & 4.25 & 1.50 \\
\hline Mean & 3.81 & 3.94 & 4.44 & 4.44 & 4.56 & 4.56 & 4.75 & 4.75 & 4.41 & 0.94 \\
\hline
\end{tabular}

Table 1. CrUCES HL Participant DMIS Rating

\subsection{Discussion}

Study results indicate that participation in the CruCES project increased intercultural sensitivity among participating HLs. Significantly, HLs in this study on average demonstrated a higher degree of intercultural sensitivity at the outset of the project in comparison to non-HL participants, whose average DMIS ratings for the first journal ranged between 2 and 3. Though other factors might also account for this difference (i.e., previous exposure to service learning or community service, religious beliefs, etc.), it may be that HLs are already sensitive to cultural differences by virtue of their childhood exposure to different cultures and languages at home and in their home communities. If so, than HLs are well positioned to take advantage of, positively contribute to, and benefit from service learning opportunities.

In the case of the two exceptions in this study, the student showing no visible increase along the DMIS scale demonstrated a keen awareness and sensitivity toward cultural and socio-economic differences that remained consistent throughout. The difference, however, was in how these perceptions translated in terms of the student's personal level of engagement with the project and community. As intercultural sensitivity developed among the other HLs, so too did their interactions with the community. In the case of the student in question, he/she clearly recognized the value of service learning for fostering intercultural sensitivity and competence, though he/she chose to retain a degree of personal distance in the project. Given that engagement and appropriate engagement, as deemed by the community in question, is one of the indicative markers of one's intercultural sensitivity and competence, this particular student's lack of personal investment in sharing with and developing relationships among his/her fellow community members (i.e., the students and people at Caritas) resulted in a lack of progression along the DMIS categories. Possible reasons for this student's lack of investment may include personal circumstances, such as family and home life, and time constraints, such as balancing service learning with school 
workload, work, and family/personal life. This suggests that HLs, though demonstrating a high degree of cultural sensitivity, are not necessarily predisposed or therefore willing to fully engage and participate in service learning opportunities by virtue of being HLs alone. This also suggests that participation in service learning alone does not necessarily guarantee that students will internalize and enact their awareness of cultural sensitivity, and thus not achieve the sort of growth and personal transformation seen among other students.

The other $\mathrm{HL}$ demonstrating a lack of growth in ISD presents another unique and telling scenario for ISD. He/She began between a 3 and a 4 along the DMIS scale, showed initial gains in intercultural sensitivity, experienced a regression by the sixth journal, and finished the semester between a 3 and 4. The reasons for the decline along the DMIS scale are related to the student's lack of reflection in the journal entries as well as negative comments relating to his/her frustrations with group work and in working with his/her group and group leader specifically. This negative disposition toward group work, which reflected a pessimistic view of people's capacity to work together and to help one another in unselfish ways, informed his/her perspective of the group project and therefore his/her ability to integrate and work effectively with his/her group. By the end of the project and as a result of his/her experience and reflections on the project, however, his/her perspective had become more positive and optimistic, hence the increase in the DMIS ratings by the final two journals.

It is important to note that though the final journal's DMIS rating is the same as that of the first journal, the student's degree of intercultural sensitivity is not the same. As the student him/herself commented by the end of the journal, he/she had experienced a change in attitude that impacted his/her outlook and personality for the better. This supports Deardorff's notion that the development of intercultural competence and sensitivity is a lifelong process that begins with, and feeds back into, one's attitudes. It is arguable that even though this student experienced a clear regression and no overall gain along the DMIS scale, he/she perhaps experienced the greatest gain in intercultural sensitivity among his/her peers as evident by his/her significant transformation in attitude. With subsequent service learning or other intercultural experiences, he/she will be better equipped to work and interact with others, and will only potentially grow in his/her intercultural sensitivity and competence. Whether or not such growth and transformation is linked to one's cultural heritage and linguistic abilities remains to be seen.

\section{Conclusion}

Findings show that the CruCES project HL participants demonstrated a high degree of intercultural sensitivity at the outset of the project and experienced positive gains overall in intercultural sensitivity. As shown above, the average HL journal DMIS rating for journal 1 and 8 were 3.81 and 4.75 respectively, with an average increase along Bennett's stages of .95. These findings corroborate those of the pre- and post-project surveys, which likewise indicated that students initially maintained a high perception of their intercultural sensitivity while at the same time perceived growth in their intercultural sensitivity as a result of participating in the CruCES project. Though 
progress along Bennett's DMIS stages was not necessarily linear for all HL participants, all HLs nonetheless experienced a positive transformation in overall attitudes related to ideas about community, CSL, language and culture, and difference as indicated by their visual and written reflections. In addition, many of the HLs perceived an increase in self-confidence and self-esteem as a result of participating in the project and using their language skills in specific and relevant ways.

The results suggest that the value of CSL for ISD within an LSP or other language course may be in providing the framework necessary to achieve a positive transformation in student attitudes regarding difference and community service. This is to say that perhaps what is most important is not how far along Bennett's DMIS stages students progress during a given CSL project, but rather that they emerge from the CSL experience with a new mindset or worldview. For HLs, this is especially important given the diversity of backgrounds and experiences with the Spanish language. Though HLs may demonstrate a higher awareness of cultural sensitivity at the outset of a CSL project, they may not necessarily experience higher gains in intercultural sensitivity in comparison to non-HLs. This does not mean, however, that HL ISD benefits any less from CSL. Indeed, this study shows that CSL may well be a transformative experience for HLs.

\section{LFE About the author}

An assistant professor of Spanish at the University of Memphis specializing in LSP and CSL, Diana Ruggiero develops undergraduate and graduate courses in Spanish for specific purposes with an emphasis on CSL. Thanks to a Strengthening Communities Capacity Building Grant, she developed Spanish language course combining LSP and CSL. Her research encompasses LSP curriculum development, CSL, ISD, and HLS and is integrally linked to her teaching and service. She has presented her research at national and international conferences, including the ACTFL Annual Convention and World Language Expo, the MLA Annual Convention, the International Symposium on Language for Specific Purposes/Ciber Business Language Conference, and the European Association of Languages for Specific Purposes (AELFE) International Conference. Her publications have appeared in the Journal of Languages for Specific Purposes, Global Business Languages, the Journal of Community Engagement and Scholarship, and Hispania.

\section{LFE Acknowledgements}

Support for this study was provided by the University of Memphis Strengthening Communities Capacity Building Grant and the Engaged Scholarship Faculty Committee, Onie Johns and Caritas Village, Richard Lou and the Centro Cultural Latino de Memphis, the University of Memphis Department of World Languages and Literatures, the CruCES project community leaders, the community of West 
Binghampton, and the students of Span 4703.

\section{LFE Article history}

Paper received: 30th August 2016

Paper received in revised form and accepted for publication: 19th February 2017

\section{References}

Abbott, A. \& Lear, D. (2010). The connections goal area in Spanish community service learning: possibilities and limitations. Foreign Language Annals, 43, 231-245.

Barreneche, G. (2011). Language learners as teachers: Integrating service learning and the advanced language course. Hispania, 94(1), 103-20.

Beaudrie, S. M. \& Fairclough, M. (2012). Introduction: Spanish as Heritage Language in the United States. In S. M. Beaudrie \& M. Fairclough (Eds.), Spanish as a heritage language in the United States: the state of the field (pp. 1-17). Washington, DC: Georgetown University Press.

Bennett, M. J. (1993). Towards ethnorelativism: A developmental model of intercultural sensitivity. In R. M. Paige (Ed.), Education for the intercultural experience (2nd ed., pp. 21-71). Yarmouth, ME: Intercultural Press.

Bennett, M. J. (2004). Becoming interculturally competent. In J. S. Wurzel (Ed.), Toward multiculturalism: A reader in multicultural education (2nd ed., pp. 62-77). Newton, MA: Intercultural Resource Corporation.

Bennett, M. J. (2008). On becoming global souls: Building intercultural competence. Paper presented at the First International Conference on the Development and Assessment of Intercultural Competence. Tucson, AZ: October 10-11, 2008.

Byram, M. (1997). Teaching and Assessing Intercultural Communicative Competence. Clevedon, UK: Multilingual Matters.

Byram, M. (2009). Intercultural competence in foreign languages: The intercultural speaker and the pedagogy of foreign language education. In D. Deardorff (Ed.), The sage handbook of intercultural competence (pp. 321-32). Thousand Oaks: Sage Publications.

Deardorff, D.K. (2006). Identification and assessment of intercultural competence as a student outcome of internationalization. Journal Studies in International Education, 10(3), 241-266.

Deardorff, D.K. (2009). Implementing Intercultural Competence Assessment. In Deardorff, D. (Ed.), The sage handbook of Intercultural Competence (pp. 477-91). Thousand Oaks: Sage Publications.

Deardorff, D. \& Edwards K. (2013). Framing and assessing students' intercultural competence in service learning. In P. Clayton, R. Bringle \& J. Hatcher (Eds.), Research on service learning: Conceptual frameworks and assessment: Communities, institutions, and partnerships (pp. 15783). Sterling, Va: Stylus Pub.

Ebacher, C. (2013). Taking Spanish into the community: A novice's guide to service-learning. Hispania, 96(2), 397-408. 
Falce-Robinson, J. \& Strother, D. (2012). Language proficiency and civic engagement: The incorporation of meaningful service-learning projects in Spanish language courses. Interdisciplinary Humanities, 29(3), 73-87.

Grassi, E., Hanley, D. \& Liston, D. (2004). Service-learning: An innovative approach for second language learners. Journal of Experiential Education, 27(1), 87-110.

Hellebrandt, J., Arries, J. \& Varona, L. (2003). Juntos: Community partnerships in Spanish and Portuguese. Boston: Thomas/Heinle.

Hellebrandt, J. \& Jorge, E. (2013). The scholarship of community engagement: Advancing partnerships in Spanish and Portuguese. Hispania, 96(2), 203-14.

Hellebrandt, J. \& Varona, L. (1999) Construyendo puentes (building bridges): Concepts and models for service-learning in Spanish. Washington, D.C.: American Association for Higher Education.

Lafford, B. (2012). Languages for specific purposes in the United States in a global context: Commentary on Grosse and Voght (1991) revisited. The Modern Language Journal, 96, 1-27.

Lear, D. (2012). Languages for specific purposes curriculum creation and implementation in the service to the U. S. community. The Modern Language Journal, 96, 158-72.

Lear, D. \& Abbott, A. (2009). Aligning expectations for mutually beneficial community servicelearning: The case of Spanish language proficiency, cultural knowledge, and professional skills. Hispania, 92(2), 312-23.

Lear, D. \& Sanchez, A. (2013). Sustained engagement with a single community partner. Hispania, 96(2), 238-51.

McBride, K. (2010). Reciprocity in service learning: intercultural competence through SLA studies. In B. Dupuy \& L. R. Waugh (Eds.), Proceedings of Intercultural Competence Conference, August 2010 (pp. 235-261). Tucson: Center for Educational Resources in Culture, Language, and Literacy (CERCCL).

Medina, A. \& Gordon, L. (2014). Service learning, phonemic perception, and learner motivation: A quantitative study. Foreign Language Annals, 47(2), 357-71.

MLA Ad Hoc Committee on Foreign Languages (2007). Foreign languages and higher education: New structures for a changed world. Profession, 12, 234-45.

National Standards Collaborative Board. (2015). World-readiness standards for learning languages, 4th edn. Alexandria: ACTFL.

Nelson, A, \& Scott, J. (2008). Spanish in the university curriculum: A successful model for community-based service-Learning. Hispania, 91(2), 446-60.

Pellettieri, J. (2011). Measuring language-related outcomes of community-based learning in intermediate Spanish courses. Hispania, 94(2), 285-302.

Pérez-Llantada, C. \& Watson, M. (Eds.), (2011). Specialized languages in the global village: A multiperspective approach. Newcastle Upon Tyne: Cambridge Scholars Pub.

Rodriguez-Sabatar, S. (2015). Service learning and intercultural competence in the Spanish as a second language classroom. Southern Journal of Linguistics, 39(1), 1-23.

Ruggiero, D. M. (2015). Bridging the community and institution gap: A sample course with civic engagement and languages for specific purposes combined. Global Business Languages, 2 , 35-48.

Ruggiero, D. M. (2016). The creating communities, engaged scholarship project (CruCES): 
Preliminary findings of a study on intercultural sensitivity and community service learning. In M.F. Litzler, J. García Laborda \& C. Martínez Tejedor (Eds.), Beyond the universe of languages for specific purposes (pp. 59-64). Alcalá de Henares: Universidad de Alcalá.

Spitzberg, B. \& Changnon, G. (2009). Conceptualizing intercultural competence. In D. Deardorff (Ed.), The sage handbook of intercultural competence (pp. 2-52). Thousand Oaks: Sage Publications.

Zapata, G. (2011). The effects of community service learning projects on L2 Learners' cultural understanding. Hispania, 94(1), 86-102. 